Cereal Research Communications 39(3), pp. 453-464 (2011)

DOI: $10.1556 / C R C .39 .2011 .3 .15$

\title{
Genetic Analysis of Traits Contributing to Stalk Sugar Yield in Sorghum
}

\author{
P. SANJANA REDDY*, B.V.S. REDDY and P. SRINIVASA RAO \\ Global Theme on Crop Improvement, International Crops Research Institute \\ for the Semi-Arid Tropics (ICRISAT), Patancheru 502 324, Andhra Pradesh, India \\ (Received 22 July 2010; accepted 1 December 2010; \\ Communicated by P.S. Baenziger)
}

Sweet sorghum (Sorghum bicolor (L.) Moench) is a potential raw material for production of ethanol that on blending in petrol is expected to meet the energy demand and address the environmental issues. Well-developed hybrid technology will make the crop remunerative to the farmers. Hence, gene action and best combining female and male parents for sugar yield in sweet sorghum (Sorghum bicolor (L.) Moench) and the association of sugar yield with other agronomic traits was studied in 171 hybrids developed by crossing 19 female parents with nine male parents in line $\times$ tester design and evaluated during both rainy and postrainy seasons of 2006. The significant differences between the seasons for all the traits suggested that these traits are greatly influenced by the environment. The lines (female parents) ICSA 38, ICSA 479, ICSA 702, ICSA 675 and ICSA 474 and the restorers (male parents), SSV 74 and SSV 84 combined well for sugar yield during rainy season and the lines, ICSA 702, ICSA 38 and ICSA 474 and the restorers, ICSV 93046, SPV 1411 and ICSV 700 combined well during postrainy season. The magnitude of SCA variance was higher suggesting the importance of non-additive gene action in inheritance of all the traits though both additive and dominant genes controlled overall sugar yield during both the seasons. Hence, selection in early generation would be ineffective and recurrent selection with periodic intercrossing is advocated. However, breeding good combining restorer parents can fetch high sugar yield in postrainy season. There is an indication of existence of transgressive segregation for sugar yield that can be exploited. The sugar yield was weak though significantly correlated with high brix and poor grain yield during both the seasons requiring extensive crossing to improve these traits simultaneously. Keeping in view mean performance, SCA effects and heterobeltiosis, the hybrids, ICSA $474 \times$ SSV 84, ICSA $24001 \times$ ICSR 93046 and ICSA $474 \times$ SPV 422 were identified promising for rainy season and the hybrids ICSA $24001 \times$ SPV 1411 and ICSA $511 \times$ ICSV 93046 were identified for postrainy season.

Keywords: sweet sorghum, sugar yield, combining ability, gene action, postrainy season, heterosis

\footnotetext{
* Corresponding author; E-mail: sanjana@sorghum.res.in
} 


\section{Introduction}

Sorghum (Sorghum bicolor (L.) Moench) is the fifth most important cereal crop in the world after wheat, rice, maize and barley (FAO 2004). With $\mathrm{C}_{4}$ photosynthetic pathway, tolerance to drought, water logging, high salinity and acidic soils, it is a preferred crop for cultivation on marginal lands and an important source of food, fodder and income to the farmers in these regions. Sorghum was grown in $44.9 \mathrm{~m}$ ha across the globe with a production of $65.5 \mathrm{~m}$ tons and an average productivity of $1.5 \mathrm{t} \mathrm{ha}^{-1}$ in 2008 (http://faostat.fao.org/ verified on 5 February 2010). There is a need to improve overall income from sorghum through improving productivity or exploring for other alternative uses. Sweet sorghum is similar to commonly grown grain sorghum with a potential to accumulate sugars in the stalk. The global energy demand and volatile prices of fossil fuels forced nations to search for new alternative energy sources. Sweet sorghum, with its short growing period (four months), low water requirement, high biomass and alcohol production potential and greater income potential from cultivation, is a preferred raw material. In addition to sweet-stalk, a grain yield of about 2.0 to $6.0 \mathrm{t} \mathrm{ha}^{-1}$ (which can be used as food or feed) could be harvested from sweet sorghum.

The wide range of variability for Brix (3 to 25\%; Sankarapandian et al. 1994; Almodares et al. 1997; Elangovan et al. 2007), sucrose (7.2 to 15.5\%; Almodares et al. 1997) and fresh stalk yield (24 to $150 \mathrm{t} \mathrm{ha}^{-1}$; Sankarapandian et al. 1994; Elangovan et al. 2007) in sorghum indicates the high potential for genetic improvement to produce high sweet-stalk yield coupled with high sucrose and fermentable sugars (glucose and fructose). Total sugars are found to be highly correlated with sucrose $\%(r=0.98)$ in sweet sorghum stalks (Krishnaveni et al. 1990). The predominant role of non-additive gene action and substantial magnitude of standard heterosis for all the traits related to ethanol production (plant height: up to $46.9 \%$, stem girth: up to $5.3 \%$, TSS (\%): up to $7.4 \%$, millable stalk yield: up to $1.5 \%$ and extractable juice yield: up to $122.6 \%$ ) was reported (Sankarapandian et al. 1994). However, season specificity and high $\mathrm{G} \times \mathrm{E}$ interactions exists among the sweet sorghum genotypes. Knowing general (GCA) and specific (SCA) combing ability effects of genetic materials is of practical value in breeding programs. Both components play an important role in selecting superior parents for hybrid combinations and represent a powerful method to measure the nature of gene action involved in quantitative traits (Baker 1978). GCA effects represent the fixable component of genetic variance, and are important to develop superior genotypes. SCA represents the non-fixable component of genetic variation and it is important to provide information on hybrid performance. Line $\times$ tester analysis is easy and comprehensive in obtaining genetic basis of population, and it provides information about GCA and SCA of inbred lines. It is also helpful in estimating various types of gene effects.

The current study was targeted to identify the best combiners for sugar yield and to study the gene action and association of traits governing sugar yield in sweet sorghum in both rainy and postrainy seasons and to derive a breeding approach based on the nature of genes governing sugar yield and related traits. The study envisaged assessing the general combining ability of parents and specific combining ability of crosses and nature of gene 
action involved in inheritance of sugar yield related traits by following a line $\times$ tester $(\mathrm{L} \times \mathrm{T})$ design. Expression and magnitude of heterosis and correlation is necessary for understanding the genetic and selection basis of sweet sorghum.

\section{Materials and Methods}

\section{Plant materials}

The experimental material consisted of 19 females/cytoplasmic male-sterile (CMS) lines (hereby referred to as lines). Fourteen of the lines are in $A_{1}$ cytoplasm (ICSA 38, ICSA 84, ICSA 95, ICSA 102, ICSA 24001 and ICSA 89002 are high yielding, ICSA 285 is resistant to anthracnose, ICSA 344 is resistant to rust, ICSA 474, ICSA 475, ICSA 479 are resistant to stem borer, ICSA 502, ICSA 511 are resistant to midge, ICSA 675 is a staygreen line) and five are in non-milo cytoplasmic background (ICSA 702, ICSA 724, ICSA 730, ICSA 731 are lines in $A_{2}$ cytoplasm, ICSA 749 is a line in $A_{3}$ cytoplasm). Thus the CMS lines represent a broader pool of germplasm. The nine male parents/restorer lines (hereby referred to as testers) that include Ent. 64 DTN, ICSR 93034, ICSV 700, ICSV 93046, NTJ 2, SPV 1411, SPV 422, SSV 74 and SSV 84 have significant differences among them for sugar yield. The lines had Brix $>10$ and testers had Brix $>14$ in the trials conducted earlier at ICRISAT, Patancheru from 2002-2005 (ICRISAT Annual Reports 2003 to 2006).

\section{Experiment}

The $171 \mathrm{~F}_{1}$ hybrids were produced by crossing 19 lines with 9 testers in a $\mathrm{L} \times \mathrm{T}$ mating design during the 2005 post-rainy season. The hybrids were planted in a randomized complete block design (RCBD) in three replications during the 2006 rainy and postrainy seasons at the International Crops Research Institute for the Semi-Arid Tropics (ICRISAT), Patancheru, India. Each genotype was sown in two-row plots of two-m row length; the rows were $75 \mathrm{~cm}$ apart and a distance of $15 \mathrm{~cm}$ was maintained between plants in a row. Standard crop production and protection practices were followed to raise a healthy crop. The experimental site is located at an altitude of $545 \mathrm{~m}$ above mean sea level, latitude of $17.53^{\circ} \mathrm{N}$ and longitude of $78.27^{\circ} \mathrm{E}$.

\section{Data collection}

Ten random plants per plot were tagged (data on 10 random plants was found to give a low desirable $\mathrm{CV} \%$ ( $<20 \%$ for quantitative traits) at ICRISAT and is feasible for recording observations in trials with large number of genotypes in sweet sorghum experiments) and the data were collected for the traits days to $50 \%$ flowering (days taken to flower $50 \%$ of the plants in a plot), plant height (average height in $\mathrm{m}$ from the base of the plant to the tip of the panicle), stalk weight (weight in $\mathrm{tha}^{-1}$ of the stalks without panicles harvested at physiological maturity), cane weight (stalk weight after removal of leaves and sheath), juice weight (weight of juice in $\mathrm{tha}^{-1}$ extracted by crushing the canes), bagasse weight (weight of stalks after juice extraction in $\mathrm{tha}^{-1}$ ), Brix and sugar yield (calculated as per Putnam et al. (1991) as a product of Brix in \% and juice weight and expressed in $\mathrm{t} \mathrm{ha}^{-1}$ ) during both 
the seasons and grain yield (weight of the grain after threshing panicles expressed in $\mathrm{tha}^{-1}$ ) during 2006 postrainy season.

\section{Biometric-genetic analysis}

The genotypes were considered fixed while the seasons were considered as random effects. Separate analysis of variance (ANOVA) of RCBD model for individual seasons were done to test the significance of differences among the $F_{1} s$. A combined analysis was also performed to test the significance of the hybrid $\times$ season interaction. Combining ability analysis based on the data combined over seasons was similar to those described by Ross et al. (1983). The sum of squares due to $F_{1}$ hybrids was partitioned into sum of squares due to lines, testers, and line $\times$ tester, which was used to estimate the additive and dominance components of the variation. The tests of significance of hybrids, lines, testers, and line $\times$ testers for each trait were made by testing these mean squares with their respective year interaction mean squares when these interaction effects were significant, other wise pooled error mean squares were used. The mid-parent heterosis was worked out following Singh and Narayanan (1993). Simple correlations were performed to understand the association between the morphological traits. The main effects of CMS and restorer lines were equivalent to general combining ability (GCA), and the effects of a CMS line with a specific restorer were equivalent to specific combining ability (SCA) (Hallauer and Miranda 1981). The proportional contribution of lines, testers, and their interaction to total variability of each trait/character was also computed. The distribution of crosses in relation to general combining ability (GCA) and specific combining ability (SCA) effects was worked out by taking combining ability effects as significant positive (high $=h$ ), non-significant (average $=a$ ) and significant negative (low $=l$ ). However, for days to flowering, significant positive combining ability effects were taken as low, non-significant as average and significant negative as high. The analysis was done using Genstat 12 edition.

\section{Results}

\section{Analysis of variance}

Individual analysis of variance (ANOVA) for rainy and postrainy seasons depicted highly significant differences between hybrids for all the traits. The error variances in the trials conducted in two years were homogeneous, as revealed by Bartlett's test (Bartlett 1937), providing statistical validity to carry out combined ANOVA. In ANOVA combined across seasons, significant differences were observed among the hybrids for all the traits except for days to 50\% flowering, plant height and Bagasse weight (Table 1). Partitioning of the hybrid source of variation into lines, testers and line $\times$ tester, revealed that the greater part of variability (as seen by the magnitude of respective mean sum of squares) observed for days to $50 \%$ flowering, juice weight, grain yield and sugar yield could be attributed to testers while for Brix, lines contributed more. For stalk weight, cane weight and bagasse, lines and testers contributed almost equally. Like the main hybrid effect, where the male parents contributed too much of the variation, the tester $\times$ season interaction 
made a greater contribution to variation in hybrid $\times$ season interaction effects than did line $x$ season interaction which was more than the tester mean sum of squares for most of the traits. Tadesse et al. (2008) reported the variable expression of morpho-agronomic traits in relation to the environment considered, which is a common problem in the SAT. Such a problem can be minimized through conducting multilocational experiments for each season. The mean squares due to line $\times$ tester interaction were significant for all the traits. The line $\times$ tester $\times$ season interactions were significant for days to $50 \%$ flowering, stalk weight, bagasse weight, Brix $\%$, grain yield and sugar yield. The differences between the seasons were significant for all the traits and the rank correlation was significant suggesting cross over type of genetic interaction. The genotypes are specific to the season and hence the results are presented for the individual seasons.

\section{Genetic components of variance}

The estimates of genetic components of variance together with related genetic parameters for various traits/characters are presented in Table 2. The magnitude of SCA variance was more than their corresponding GCA variance for all the characters. The testers had a higher GCA variance as compared to lines for days to $50 \%$ flowering, stalk weight, cane weight and bagasse weight during both the seasons and for juice weight, sugar yield and grain yield during postrainy season. The lines had a higher GCA variance compared to testers for Brix during both the seasons and for juice weight during rainy season. The GCA variance due to lines and testers were similar for sugar yield during rainy season. The average degree of dominance indicated over dominance $(>1)$ for all the characters in both the environments. The contribution of line $\times$ tester interaction was more to total variation in all the traits studied when compared with either lines or testers for all the traits except days to $50 \%$ flowering (during both seasons). The contribution of line $\times$ tester interaction to the total variation ranged from 40 to $71 \%$ while for the traits days to $50 \%$ flowering, the testers contribution ranged from 50 to $62 \%$.

\section{General combining ability (GCA) effects}

The female lines ICSA 38, ICSA 479, ICSA 702, ICSA 675 and ICSA 474 combined well for sugar yield during rainy season and the female lines ICSA 702, ICSA 38 and ICSA 474 combined well during postrainy season. Among these lines, the female line ICSA $38 \mathrm{com}-$ bined well for greater cane and juice yields during both rainy and postrainy seasons, for bagasse yield and late flowering during rainy season. ICSA 474 combined well for early flowering and high juice yield during both the seasons and for cane and bagasse yields during rainy season. ICSA 479 combined well for high Brix and early flowering during rainy season. ICSA 675 combined well for cane and juice yields during rainy season and bagasse and grain yields during postrainy season. However, it contributed to delay in flowering during both the seasons. Apart from sugar yield, ICSA 702 combined well for Brix during both the seasons. While among the R-lines, SSV 74 and SSV 84 during rainy season and ICSV 93046, SPV 1411 and ICSV 700 during postrainy season combined well for sugar yield. The R-lines SSV 74 and SSV 84 also combined well for cane yield, juice 


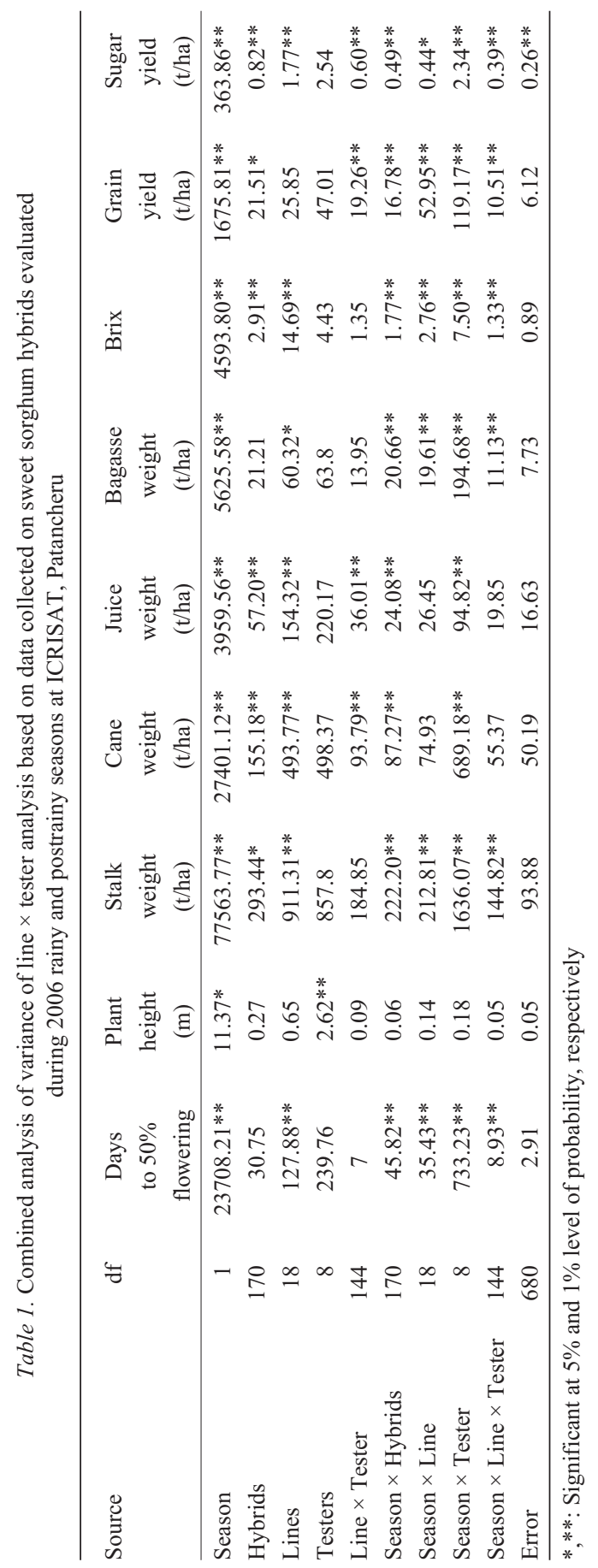

Cereal Research Communications 39, 2011 


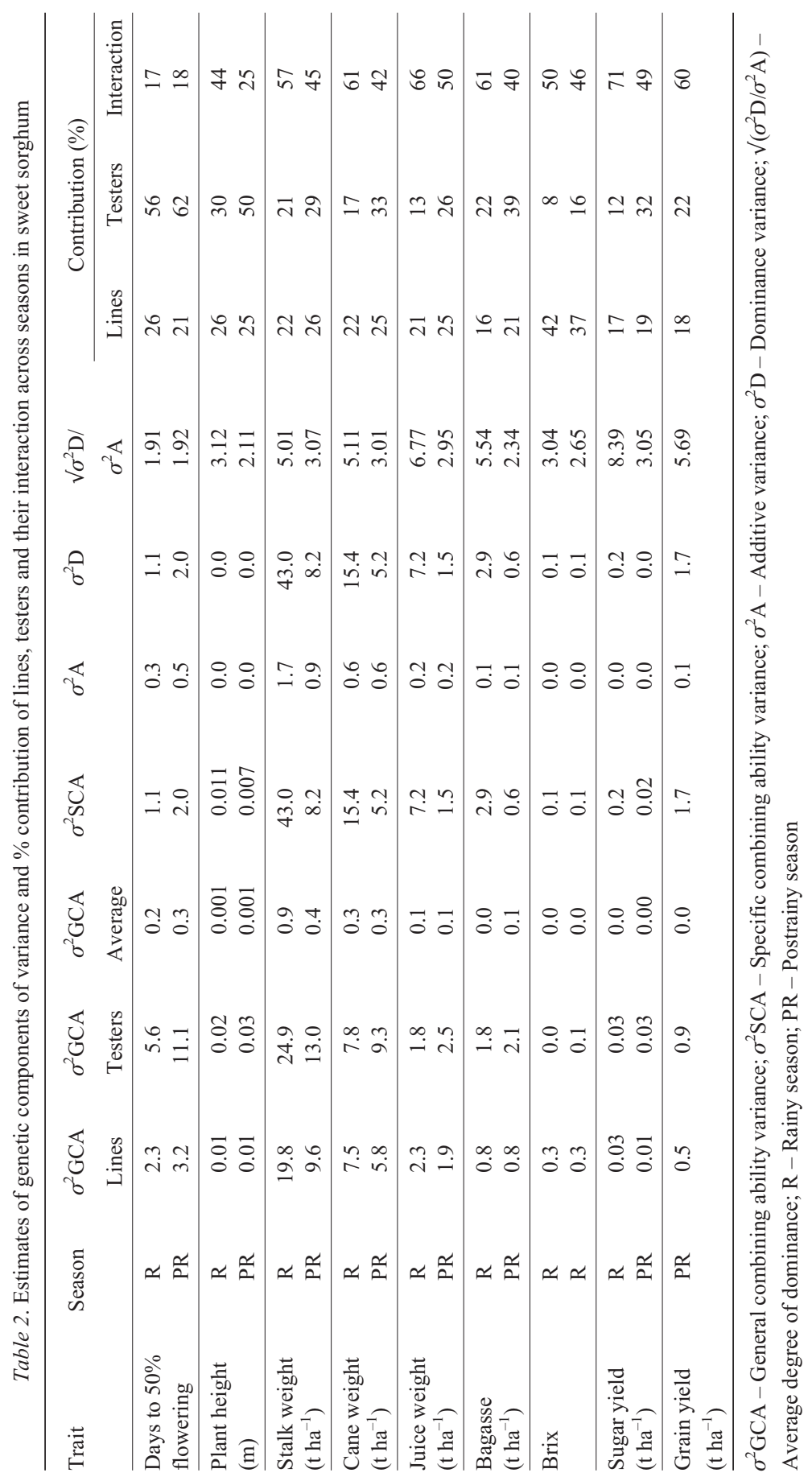

Cereal Research Communications 39, 2011 
yield and bagasse yield during rainy season. However, they contributed to late flowering during rainy season. The restorers ICSV 93046, SPV 1411 and ICSV 700 also combined well for greater cane yield, juice yield, bagasse and Brix (except for SPV 1411). However, they contributed to late flowering during postrainy season.

\section{Specific combining ability (SCA) effects and heterosis}

For sugar yield, 12 hybrids in rainy season and four hybrids in postrainy season had significant positive SCA effects. The hybrid ICSA $730 \times$ ICSV 700 had the highest positive and significant SCA effect (1.22) followed by ICSA $479 \times$ Ent. 64 DTN (1.19) while the hybrid, ICSA $474 \times \operatorname{SSV} 84\left(4.2 \mathrm{tha}^{-1}\right)$ followed by ICSA $24001 \times \operatorname{ICSV} 93046\left(4.0 \mathrm{tha}^{-1}\right)$ and ICSA $474 \times$ SPV $422\left(4.0 \mathrm{tha}^{-1}\right)$ had the highest sugar yield among the 12 hybrids in the rainy season. During postrainy season, the SCA effects among the four hybrids ranged from 0.45 to 0.56 while the hybrids ICSA $24001 \times \operatorname{SPV} 1411\left(2.3 \mathrm{tha}^{-1}\right)$ and ICSA $511 \times$ ICSV $93046\left(2.1 \mathrm{t} \mathrm{ha}^{-1}\right)$ had high sugar yield per se.

\section{Association of sugar yield with other agronomic traits}

High sugar yield was significantly and strongly correlated with higher stalk weight $(0.79$, $0.82)$, high cane weight $(0.91,0.89)$, high juice weight $(0.95,0.91)$ and high bagasse weight $(0.78,0.72)$ during rainy and postrainy seasons, respectively. However, the sugar yield was weak though significantly correlated with late flowering $(0.38,0.48)$, high brix $(0.30,0.36)$ during both the seasons and poor grain yield $(-0.36)$ during postrainy season.

\section{Discussion}

The hybrids differed significantly for all the traits during both rainy and postrainy seasons validating the material for further study. From the ANOVA combined across seasons, it is observed that the male parent was important for improving juice yield and overall sugar yield (as seen by the magnitude of tester mean sum of squares) in sweet sorghum hybrid breeding program while for Brix, lines contributed more. For stalk weight, lines and testers almost contributed equally. Though improving the juice yield in the male parent improved the sugar yield of the hybrids, breeding for female parents with high Brix and both the parents with high biomass will improve these traits in the hybrids and in turn contribute to the sugar yield in the hybrids (these are positively and significantly correlated with sugar yield). The significant line $\times$ tester mean squares for all the traits indicated the significant contribution of SCA variance components and heterosis. However, the heterosis of the traits, days to $50 \%$ flowering, stalk weight, bagasse weight, Brix $\%$, grain yield and sugar yield were influenced by the environment. The mean value of the traits was significantly influenced by the season. The genotypes are specific to the season and hence the results are discussed separately for the individual seasons.

The high GCA effects are attributed to additive gene effects or additive $\times$ additive interaction effects and represent a fixable portion of genetic variation (Sarma et al. 2004). The testers combined well for days to $50 \%$ flowering, stalk weight, cane weight and bagasse weight during both the seasons and for juice weight, sugar yield and grain yield during 
postrainy season. The lines combined well for Brix during both the seasons and for juice weight during rainy season. However, the lines and testers contributed equally for sugar yield during rainy season. The male parent was important for improving juice yield and overall sugar yield is postrainy season where the crop is naturally subjected to moisture (despite irrigating at regular intervals) and low temperature stress while both the parents, the male parent with high biomass and female parent with high juice yield, contributed equally to sugar yield during the rainy season. Hence for improving the sugar yield in rainy season, female parents with high Brix and Juice yields and male parents with high biomass are required and for improving sugar yield in postrainy season, female parents with high brix and male parents with high stem juice content are required. The female lines ICSA 38, ICSA 479, ICSA 702, ICSA 675 and ICSA 474 combined well for sugar yield while ICSA 479 combined well for high Brix and ICSA 38 for juice yield during rainy season. The female parent ICSA 702 combined well for Brix during both the seasons. While among the R-lines, SSV 74 and SSV 84 combined well for stalk weight and sugar yield during rainy season and ICSV 93046, SPV 1411 and ICSV 700 combined well for juice yield and sugar yield during postrainy season.

However, the non-additive gene action was important for all the traits as the SCA variance was greater than the GCA variance (Table 2 ). The greater contribution of line $\times$ tester interaction compared with either lines or testers for all the traits except days to $50 \%$ flowering (during both seasons) indicated the importance of specific hybrid combinations in realizing heterotic hybrids and also indicated that upon crossing sufficient genetic variability can be obtained for these traits. The over dominance (average degree of dominance $>1$ ) reported for all the characters in both the seasons can be exploited in breeding programs. The hybrids with significant and positive SCA effects for sugar yield also had high mean sugar yield as seen by the relative ranking of the hybrids in the respective seasons. Most of these hybrids also had significant positive SCA effects for stalk weight, cane weight and juice weight.

The mean per se performance of the hybrids for sugar yield with the GCA effects of parents, SCA effects and heterosis of top ten high sugar yielding hybrids during both rainy and postrainy seasons is given in Table 3 . During rainy season, all the ten hybrids had significant mid-parent heterosis, seven hybrids had significant SCA effects, seven hybrids had good combining females and three hybrids had good combining males in positive direction and all the hybrids had either one or a combination of significant GCA and SCA effects denoting the role of both additive and dominant genes in controlling overall sugar yield during rainy season. During postrainy season also, all the ten hybrids had significant positive mid-parent heterosis. Hence utilization of heterosis for improving sugar yield is rewarding. All the 10 hybrids had good combining males and three among them had good combining females and two had significant SCA effects. This shows the importance of breeding good combining restorer parents for obtaining high sugar yield in postrainy season.

The distribution of crosses in relation to GCA effects of parental combinations $(h \times h, h$ $\times a, h \times l, l \times h, l \times a, l \times l, a \times h, a \times a$ and $a \times l)$ showed that almost all types of SCA effects were obtained from varied kinds of GCA effects $(h \times h, h \times a, h \times l, a \times h, a \times a$ and $l \times h)$ 
Table 3. Mean performance, GCA effects of parents, SCA effects and mid-parent heterosis of top ten sweet sorghum hybrids for sugar yield during 2006 rainy and postrainy seasons

\begin{tabular}{|c|c|c|c|c|c|}
\hline Hybrid & $\begin{array}{l}\text { Sugar yield } \\
\left(\mathrm{t} \mathrm{ha}^{-1}\right)\end{array}$ & $\begin{array}{l}\text { GCA } \\
\text { line }\end{array}$ & $\begin{array}{l}\text { GCA } \\
\text { tester }\end{array}$ & SCA & $\begin{array}{l}\text { Mid-parent } \\
\text { heterosis }\end{array}$ \\
\hline \multicolumn{6}{|l|}{ Rainy season } \\
\hline $\mathrm{ICSA} 38 \times \mathrm{SSV} 84$ & 4.2 & $0.38 * *$ & $0.19 *$ & 0.61 & $66 * *$ \\
\hline ICSA $474 \times$ SSV 84 & 4.2 & $0.25 *$ & $0.19 *$ & $1.11 * *$ & $40 * *$ \\
\hline ICSA $24001 \times$ ICSV 93046 & 4.0 & 0.21 & -0.02 & $1.13 * *$ & $64 * *$ \\
\hline ICSA $474 \times$ SPV 422 & 4.0 & $0.25 *$ & 0.00 & $1.05 * *$ & $53 * *$ \\
\hline ICSA $479 \times$ Ent. 64 DTN & 3.8 & $0.31 * *$ & $-0.31 * *$ & $1.19 * *$ & $59 * *$ \\
\hline ICSA $24001 \times$ SSV 74 & 3.8 & 0.21 & $0.38 * *$ & 0.56 & $53 * *$ \\
\hline ICSA $675 \times$ SPV 422 & 3.8 & $0.27 *$ & 0.00 & $0.90 * *$ & $71 * *$ \\
\hline ICSA $479 \times$ NTJ 2 & 3.7 & $0.31 * *$ & 0.14 & 0.65 & $58 * *$ \\
\hline ICSA $730 \times$ ICSV 700 & 3.7 & -0.05 & -0.11 & $1.22 * *$ & $57 * *$ \\
\hline ICSA $702 \times$ SPV 1411 & 3.7 & $0.28 *$ & $-0.17 *$ & $0.87 * *$ & $53 * *$ \\
\hline \multicolumn{6}{|l|}{ Postrainy season } \\
\hline ICSA $24001 \times$ ICSV 93046 & 2.8 & 0.13 & $0.27 * *$ & -0.33 & $49 * *$ \\
\hline ICSA $24001 \times$ SPV 1411 & 2.3 & 0.13 & $0.24 * *$ & $0.54 * *$ & $37 * *$ \\
\hline ICSA $84 \times$ SPV 1411 & 2.1 & 0.11 & $0.24 * *$ & 0.35 & $45 * *$ \\
\hline ICSA $474 \times$ ICSV 93046 & 2.1 & $0.13 *$ & $0.27 * *$ & 0.29 & $36 * *$ \\
\hline ICSA $511 \times$ ICSV 93046 & 2.1 & $-0.16^{*}$ & $0.27 * *$ & $0.56 * *$ & $53 * *$ \\
\hline ICSA $749 \times$ ICSV 93046 & 2.0 & 0.10 & $0.27 * *$ & 0.10 & $35 * *$ \\
\hline ICSA 38 × ICSV 93046 & 2.0 & $0.14^{*}$ & $0.27 * *$ & 0.17 & $48 * *$ \\
\hline ICSA $749 \times$ ICSV 700 & 2.0 & 0.10 & $0.15 * *$ & 0.32 & $30 *$ \\
\hline ICSA $702 \times$ ICSV 93046 & 2.0 & $0.17 * *$ & $0.27 * *$ & 0.19 & $30 *$ \\
\hline ICSA $102 \times$ ICSV 93046 & 2.0 & -0.04 & $0.27 * *$ & 0.20 & $46 * *$ \\
\hline
\end{tabular}

*, **: Significant at $5 \%$ and $1 \%$ level of probability, respectively

and hence performance of hybrids was independent of parents especially during rainy season while high combining tester played an important role in postrainy season. In these hybrids, both additive and non-additive, i.e. dominant and epistatic type of gene action seemed to control sugar yield. Similar results were reported in tomato (Thakur et al. 2004) and rice (Hariprasanna et al. 2006). Transgressive segregation is a mechanism for rapid evolutionary transitions because hybridization generates variation at many genes simultaneously and the variant alleles have already been tested by selection. The crosses having one parent with high GCA effects and other parent with low GCA effects are expected to throw desirable transgressive segregates if the additive genetic system present in high combiner and complementary epistatic effects act in same direction (Iqbal and Khan 2003). The situation was well reflected in promising crosses ICSA $479 \times$ Ent $64 D T N$, and ICSA $702 \times$ SPV 1411 during rainy season and in the cross ICSA $511 \times$ ICSV 93046 during postrainy season for sugar yield.

Improvement in stalk yield or juice yield will cause a simultaneous improvement in sugar yield as these traits are significantly and positively correlated. The Brix and grain yield have to be improved in high biomass and high juicy stem back grounds though improvement in grain yield in high sugar background requires extensive crossing and it is possible as the correlation obtained is weak though negative. 


\section{Breeding strategy}

Since improvement in sugar yield is the most important parameter for which low additive gene action was depicted in addition to preponderance of non-additive gene action as revealed by other genetic parameters as well, selection in early generation would be ineffective and recurrent selection with periodic intercrossing is advocated. Duvick (1999) reported that high degree of heterosis did not essentially correlate to SCA effects, as seen in the present study therefore, genotype $\times$ environment interaction studies have to be conducted as suggested by Bakhsh et al. (2006). It is also evident from the current study that the testers like ICSV 93046, SPV 1411 and ICSV 700 played an important role in exploitation of heterosis for sugar yield in postrainy season while both good combining females, males and the specific hybrid combinations were important in realizing high sugar yield during rainy season. Apart from this, there is an indication of existence of transgressive segregation which can be exploited.

Keeping in view mean performance, SCA effects and heterobeltiosis, the hybrids, ICSA $474 \times$ SSV 84, ICSA $24001 \times$ ICSV 93046 and ICSA $474 \times$ SPV 422 during rainy season and the hybrids ICSA $24001 \times$ SPV 1411 and ICSA $511 \times$ ICSV 93046 for postrainy season can be further tested in multilocation trials for stability.

\section{References}

Almodares, A., Sepahi, A., Shirvani, M. 1997. Sweet sorghum cultural practices in Iran. In: Li Dajue (ed.), Proceedings of the First International Sweet Sorghum Conference, 14-19 Sep. 1997, Beijing, China Institute of Botany, Chinese Academy of Sciences, Beijing, China, pp. 175-183.

Baker, R.J. 1978. Issues in diallel analysis. Crop Sci. 18:533-536.

Bakhsh, A., Arshad, M., Haqqani, A.M. 2006. Effect of genotype $\times$ environment interaction on relationship between grain yield and its components in chickpea (Cicer arietinum L.). Pak. J. Bot. 38:683-690.

Bartlett, M.S. 1937. Some examples of statistical methods of research in agriculture and applied biology. J. Royal Stat. Soc. 4:137-170.

Duvick, D.N. 1999. Heterosis: Feeding people and protecting natural resources. In: Coors, J.S., Pandey, S. (eds), The Genetics and Exploitation of Heterosis in Crops. Am. Soc. Agr. Inc., Crop Sci. Soc. Am., Inc., Soil Sci. Soc. Am., Inc., Madison, WI, USA, pp. 19-29.

Elangovan, M., Prabhakar, P., Reddy, D.C.S. 2007. Characterization and evaluation of sorghum [Sorghum bicolor (L.) Moench] germplasm from Karnataka, India. J. of Agric. Sci. 20:840-842.

FAO. 2004. Production Yearbook. Rome, Italy.

Hallauer, A.R., Miranda, J.B. 1981. Quantitative Genetics in Maize Breeding. Iowa State Univ. Press, Ames, IA, USA.

Hariprasanna, K., Zaman, F.U., Singh, A.K., Tomar, S.M.S. 2006. Analysis of combining ability status among parents and hybrids in rice (Oryza sativa L.). Indian J. of Genet. and Plant Breed. 66:28-30.

Iqbal, M.Z., Khan, S.A. 2003. Line $\times$ Tester analysis in true seed of potato (Solanum tubersum spp tubersum). J. of Biological Sci. 3:674-680.

Krishnaveni, S., Balasubramanian, T., Sadasivam, S. 1990. Potentiality of sweet sorghum (Sorghum bicolor) for syrup preparation and alcohol production in India. Economic Bot. 44:355-359.

Putnam, D.H., Lueschen, W.E., Kanne, B.K., Hoverstad, T.R. 1991. A comparison of sweet sorghum cultivars and maize for ethanol production. J. of Prod. Agric. 4:377-381.

Ross, W.M., Gorz, H.J., Haskins, F.A., Hookstra, G.H., Rutto, J.K., Ritter, R. 1983. Combining ability effects for forage residue traits in grain sorghum hybrids. Crop Sci. 23:97-101.

Sankarapandian, R., Ramalingam, J., Pillai, M.A., Vanniarajan, C. 1994. Heterosis and combining ability studies for juice yield related characteristics in sweet sorghum. Ann. of Agric. Res. 15:199-204. 
Sarma, R.N., Bahar, B., Borah, J., Barooah, D. 2004. Genetics of rice hispa tolerance. New directions for a diverse plant. In: Proceedings for the $4^{\text {th }}$ International Crop Science Congress, Brisbane, Australia, 26 September - 1 October 2004. http://www.cropscience.org.au/icsc2004/poster

Singh, P., Narayanan, S.S. 1993. Biometrical Techniques in Plant Breeding. Kalyani Publishers, New Delhi, India.

Tadesse, T., Tesso, T., Ejeta, G. 2008. Combining ability of introduced sorghum parental lines for major morpho-agronomic traits. J. of SAT Agric. Res. 6:1-7.

Thakur, A.K., Kholi, U.K., Joshi, A. 2004. Evaluation of diallel progeny and heterosis for yield and yield components in tomato (Lycopersicon esculentum Mill). J. of Horticultural Sci. 33:106-108. 